\title{
Outsiders within the Academy: Strategies for Resistance and Mentoring African American Women
}

\author{
Tammy L. Henderson* \\ Andrea G. Hunter* \\ Oklahoma State University University of North Carolina-Greensboro \\ Gladys J. Hildreth \\ University of North Texas
}

\begin{abstract}
* Please address all correspondence to: Dr. Tammy L. Henderson, CFLE, Oklahoma State University, 233 HES-Human Development and Family Science, Stillwater, OK 74078-6122. Phone: (405) 744-8350; Fax: (405) 744-2800; Email: tammy.henderson@okstate.edu or Dr. Andrea Hunter, School of Human and Environmental Sciences, University of North Carolina at Greensboro, $P$. $O$. Box 26170, Greensboro, NC 27402-6170, Phone: (336) 334-0091; Fax: (336) 334-5307; Email:aghunter@uncg.edu.
\end{abstract}

\begin{abstract}
Black Feminist Thought is used to identify some of the tensions experienced by African American women faculty holding positions in predominately White institutions: (a) the mammy-sapphire continuum of existence, (b) inequality without reverence to credentials and expertise, and (c) privilege and dismissing intersectionality. Peer mentoring is discussed as a tool of resistance. Other forms of resistance include: using counter narratives, identifying the issue, defining and evaluating self, relinquishing representations offered by others, seeking and using work-life resources, and securing required resources.
\end{abstract}

Key words: Black Feminist Thought, Gender, Mentoring, Peer Mentoring, Race, Resistance

We, African American women professionals in higher education, make visible the continued presence of race and gender oppression, and the hegemony that supports systems of oppression within the academy (Dillard, 2000; Patton, 2004ab). Race and gender differences in patterns of employment, rank, and personal experiences within academic units are illustrative of the interlocking nature of race and gender oppression that have multiple influences (Combs, 2003; Wright Myers, 2002), including pathways to doctorate studies, institutional hiring practices, tenure and promotion processes, organizational behavior, and professional relationships. Further, Black women are more likely to report organizational barriers to advancement and have more negative views of academic or departmental climates. They also are less likely to indicate that their scholarship is valued, that they are respected by their colleagues, and that they are 
viewed as legitimate scholars compared to White women, men of color, or White men (Thomas \& Hollenshead, 2001).

Because career advancement and greater retention rates are among the most reported benefits of mentoring, mentoring is one form of resistance to systems of oppression, organizational barriers, and other negative dynamics experienced by Black women faculty. Mentoring also reduces social isolation and helps one to manage different academic roles (Bova, 2000; Holmes, Land, \& Hinton-Hudson, 2007), making it one of the most viable coping and resistance strategies. Yet, a discussion of mentoring without acknowledging the intersections of race and gender, their implications within predominately White institutions, and forms of resistance would not address fully the needs of Black women in the academy, beckoning the use of a cultural-inclusive approach to working with African American women in the academy.

Therefore, to frame the current discussion on mentoring, we use core themes of Black Feminist Thought (Hill Collins, 1986; 1991) to situate Black women faculty in the academy. Part of our framework includes three sites of tension and resistance: (a) the Mammy-Sapphire continuum of existence, (b) inequality without reverence to credentials, expertise, and professional experiences, and (c) White privilege that dismisses the intersecting realities of racism and sexism. We then suggest a model of peer mentoring that allows for the careful integration of the socio-political tensions, such as race and gender as critical factors when mentoring African American women faculty (Benishek, Bieschke, Park, \& Slattery, 2004). Inside the current article, we offer a few biographical narratives to place a face on the issues presented.

\section{Black Feminist Thought: Articulating the "Outsider Within}

Patton (2004a) argues that "rather than the university being a place to explore diversity and to embrace diversity, universities often become complicitous in domination and oppression (p. 190)." The fracturing between the politics, language, and practices of liberal universities is the uncomfortable nexus inhabited by Black women, which positions us as outsiders within the academy (Dillard, 2000; Patton, 2004ab). Patricia Hill Collins (1986), in her classic essay on learning from the outsider within, argues that African American women scholars have the potential to use insight from their experiences at the intersections of race, gender, and class to ask new research questions, and to bring a new lens that reflects a Black woman's standpoint. Consistent with the promise of diversity and inclusion, Black women in higher education have the potential to challenge, innovate, and make evident that which was unseen by conventional disciplinary lens. Hill Collins (1986), however, acknowledges the status of outsider within academe is inherently problematic if there are no transformations in institutions in which "outsiders" are a part of, and if the meanings assigned to Black women faculty remain unchanged. Thus, African American women as "outsiders within" the academy is a metaphor that not only evokes transformative promise but also exclusion, isolation, and subordination where one's work and contributions are viewed as less valued, less critical, and less deserving of compensation and recognition. African American women recount the questioning 
of their expertise and knowledge and being made to feel as a "token hire" (Jones \& Shorter-Gooden, 2004) instead of an expert and colleague as early as during the interview process.

We offer a biographical narrative to capture the sometimes unwelcoming entrance to the academy. A faculty member recalls an interview in which she was asked: Do you know that you are a part of the Diversity Initiative aimed at hiring faculty from diverse backgrounds? The response had many dimensions; however, we offer this one for readers: When an undergraduate student is admitted to Harvard or Yale University because their parents donated money to the university or his or her parents were highly successful alumni of the university, does that student enter the university with pride and optimism or with down dread shoulders of shame?

\section{Themes in the Lives of Black Women in Academe: Tension and Resistance}

Oppression is experienced and resisted on "the level of personal biography, the group or community level of the cultural context created by race, class, and gender, and the systemic level of social institutions" (Hill Collins, 1991, p. 227). Black feminist thought articulates key themes which emerge from Black women's standpoint through which we historically have resisted oppression. They include the assertion of self-valuation and self-definition, the awareness of the interlocking nature of race, gender, and class oppression, and the importance of African American women's culture (Hill Collins, 1986). These themes represent not only tensions within the academy, but also suggest strategies and sites of resistance that Black women may engage to weather the spiritual, intellectual, and emotional assaults that attend our status as outsiders within the very core of academe. We elaborate on the aforementioned sites of tension and resistance below.

The mammy-sapphire continuum of existence. The historical images and worn-out representations of African American women populate the U. S. imagination from the $19^{\text {th }}$ century mammy to welfare queens, matriarchs, and angry, menacing, and unintelligent Black women better known as the "Sapphire" (Bova, 2000; Hill Collins, 1991; Harley, 2008; Smith, 2000). The externallydefined representations or controlling images of Black women, however, do not include that of Black women as intellectuals. Indeed, there is no popular representation of Black women as intellectuals, persons of character, and productive colleagues (Harris, 2007; Patton, 2004ab). Black women intellectuals are invisible on college campuses and CNN; there is no Henry Louis "Skip" Gates or Cornell West on which we might collectively imagine: what a Black woman intellectual is. This is not to say that there are not many prominent Black women scholars and intellectuals, but that the public recognition of our status often is framed by other professional tropes, (e.g., poet or novelist).

The absence of images and representations of Black women as intellectuals is "filled in" with the race and gendering of our roles in areas that are valued less and are seen as less integral to the academy. Harley (2008) further suggests that African American women are literally the "maids of academe." The 
race/gendering of our roles as the supportive agent whose primary reason for existing is to help others (Bova, 2000) result in Black women professors being a valuable, yet overburdened professional resource for diversity initiatives and other professional service tasks (Chesney-Lind, Okamato, \& Irwin, 2006; Few, Piercy, $\&$ Stremmel, 2007). Completing diversity-related tasks and acting as the representative of the minority perspectives on committees often result in additional demands of professional service that is not taken on by most of our colleagues. Black female faculty members, with other women, may be expected to perform social functions (e.g., organizing social functions) within our departments (Few et al., 2007). In the face of race and gender inequity, we also often struggle with demands to fulfill our own self-defined commitment to assist and mentor other marginalized persons, especially our students and junior colleagues (Chesney-Lind et al., 2006).

As Black scholars have attempted to make in-roads into the academy, we experience anew what it means to be an "outsider within" (Hill Collins, 1986). Not as a member of a domestic class within the intimate confines of White families, as so many of our mothers before us, but as tentative and often transient members of the academy and fraternity of scholars within predominantly White universities. The African American female professorate, the metaphorical Black domestic (Harley, 2008), is an experience marked with marginalization and subordination rather than privilege and domination (Harris, 2007; Patton, 2004b). Marking our difference as well as our contributions through research, instruction, and service, our narratives document how we are received (or not) by students and embraced (or not) by standard-bearer journals. Our narratives and lived experiences also document how as university citizens we often attempt to advance a professional ethic grounded in equity and social justice rather than domination and privilege. So, we pose these questions to members of higher education: Through what collage of image and representation do members of academe imagine us? What image do Black women in academe want portrayed? These questions not only highlight the need for institutional transformation, but also are the beginning of honest dialogs about the interlocking nature of race and gender oppression and its impact on the experiences of Black women faculty, and the valuing of our contributions.

Marking the other: Inequality without reverence to credentials and expertise. The experience of African American women faculty and administrators does suggest that externally-defined representations, and the hegemony that undergird them rather insidiously, find their way into the organizational practices and collegial relationships within universities (Burke, Cooper, \& Harrison, 2000; Harley, 2008; Patton, 2004ab). Black women report feelings of marginalization, isolation, and invisibility (Fries-Britt \& Kelly, 2005; Patton, 2004a; Wright Myers, 2002) while simultaneously existing under a microscope where our work, attire, language, and behaviors are scrutinized (Harris, 2007). In 2010, African American women in the academy experience the ongoing questioning and undervaluing of our scholarship, instruction, and other work (Chesney-Lind, Okamoto, \& Irvin, 2006; Smith, 2000; Wright Myers, 2002). The lack of equal 
respect toward and for the educational background, credentials, experiences, and expertise of Black women (Smith, 2000; Wright Myers, 2002) is woven in the psyche of U. S. citizens and some educators; rational thinking inside and outside of the academy continues to be trumped by long-standing views, misperceptions, and values.

African American women faculty also may find themselves regulated to teaching and service tracks (not of their own choosing), or these teaching requirements do not further their own scholarship or effectively use their expertise (Harris, 2007; Patton, 2004ab). Women of color also encounter oppressive treatment in the assignment of courses and the survivors of the unspoken, marginalized views held toward multicultural and Black studies courses, the ghetto of higher education (Wright Myers, 2002). In the area of teaching, Black women faculty often teach courses that are less valued, and less frequently are assigned to graduate courses that are a core part of the curriculum (Chesney-Lind et al., 2006; Wright Myers, 2002). Voicing concerns about unequal treatment or providing recommendations about instruction, curriculum, or research also often are ignored, devalued, and dismissed (e.g., Harley, 2008; Wright Myers, 2002). Yet, in resistance, we often need to outperform in order to be viewed as equally qualified (Carter-Black, 2008; Wright Myers, 2002). This need to outperform suggests that the Black Tax (i.e., the additional responsibilities and expectations that are associated costs of one's Blackness) has not been repealed.

White privilege used to dismiss the lived truths of racism and sexism. Expanding on Peggy McIntosh's work (1995), the interlocking nature of race and gender oppression cannot be understood without reference to race and gender privilege within predominantly White and male-dominated institutions and disciplines. White privilege is the invisible hand of support and prestige through which White colleagues are supported, advocated for, and are given access to valuable information and opportunities, and the application of best practices with respect to mentoring, tenure, and promotion (Dillard, 2000; McIntosh; Patton, 2004a). For example, the lack of resources and information, the lack of effective mentoring, and the lack of control over resources further disenfranchise Black women faculty (Franklin \& Richardson, 1972; Wright Myers, 2002;). Black women often are without this invisible hand, and the unearned entitlements associated with it. Further, it is difficult to speak to other colleagues regarding experiences of racism, sexism, privilege, and inequity because White privilege becomes the lens through which these experiences are re-interpreted and dismissed.

We share another narrative to reflect on how access to the invisible hand of information and resources and the support of those with White privilege unfolds differentially among two Black women in academe. Two colleagues who were African American women were working on a manuscript and one shared how often senior faculty members and mentors sent information to promote her professional development, such as announcements for grant proposals, different faculty awards, Call for Papers, appropriate leadership opportunities within university and professional organizations, fellowships, and other opportunities. 
Unfortunately, this was not the experience of the other colleague and the ramifications showed themselves in differential career advancements and opportunities. Both have done well in the three main university roles of scholar, educator, and citizen but one holds a more visible presence in the academy because of her contributions and work, and because colleagues and mentors gave her access to information and resources needed to advance her development. In short, she had a mentoring network of colleagues and others to reduce the ongoing stressor of being marginalized. The other colleague faced these issues alone, making the journey of annual appraisals, five-year reviews, and promotion more demeaning and demoralizing.

Students are not immune to race and gender ideologies that mark Black women faculty as "other" or as inferior. White privilege of our colleagues extends to White students and sometimes any disgruntled student. Sometimes students' racism is disguised in the words and language that suggests that the faculty member does not like students or it is hard to understand her assignments and/or lectures (Harris, 2007; Wright Myers, 2002). Further, student complaints often are viewed as accurate and credible, although students' comments, behaviors, and language may be hostile, disrespectful, and seasoned with racism and sexism (Chesney-Lind et al., 2006; Harris, 2007; Wright Myers, 2002). There also is ongoing unprofessional approach of students going directly to the department head or dean without having had a conversation with the instructor, which suggests that students hold greater credibility than Black women faculty (Chesney-Lind et al., 2006; Wright Myers, 2002). Validating student complaints by not insisting that students meet with the professor further undermines the credibility and power of the Black women professorate; it also strengthens, validates, and sustains White privilege.

Here, we offer a biographical narrative of a tenured Black female faculty member who taught a class for the first time in a research intensive university and who was the only Black faculty member in the department, which may sound familiar to some readers. An international student from an African nation accused the faculty member of being racist and she held the belief that she was not liked by said professor. When the student met with the administration, the department head shared that other students also shared concerns about the same faculty member. The faculty member was called into the department head's office and offered a list of three complaints, including the one made by the international student. Not recognizing that the document would land in her personnel file, she offered a verbal explanation, sharing that another student was being disruptive in the class and she did not realize that she had not answered the international student's question on the lecture. The faculty member merely needed to maintain order in her class. In essence, having one side of the conflict rendered the student right and empowered by the department administrator; the faculty member was left to strategize on how to advance instructional excellence and classroom order, recognizing her authority and expertise were devalued by misinformation and the privilege of student that was validated and empowered by an administrator.

The consequences of interactions as presented in the above narrative must be explored. Faculty members' appraisals and exchanges with department heads 
and others may be filled with unsubstantiated complaints, the validation of White students' racism and sexism, and the disallowing of rebuttal information from the instructor. Consequently, African American women faculty may receive lower ratings on annual appraisals and promotion and tenure reviews, strengthening the power that White students have over Black women faculty (Wright Myers, 2002). Student evaluations and unsubstantiated evidence sometimes becomes the justification for substantial lower pay increases, modifications in contracts and appointments, and the inability to be tenured and promoted. As a consequence of unleashed workplace chaos experienced by Black women who do not have the hand of privilege, whose students have greater power than they, and whose access and power to resources and information seems like a road less traveled, we psychologically resist by regrouping as well as we change our expectations and behaviors (Jones \& Shorter-Gooden, 2004).

Mentoring, Resistance, and Strategies for Black Women in Higher Education

Moving away from a hierarchical power relationship and traditional models of mentoring, we are sometimes able to regroup, resist, and change our expectations and behaviors via the supportive tool of peer mentoring. Peer or mutual mentoring is a form of group or mutual mentoring that centers on individuals who hold the functional roles of both mentor and mentee and the engagement in a mutually edifying, interdependent relationship (Mullen, 2005). For example, The National Science Foundation (NSF) has ADVANCE programs that focus on mentoring networks for women in the science, technology, engineering, and math fields to address obstacles of gendered stereotypes. ADVANCE programs seek to recruit and retain women in these and other fields, enhance their career development, and have a positive influence on the selfefficacy of women and people of color (Wagner, 2004).

If diversity, inclusiveness, and the successful performance and advancement of African American women are goals in higher education, we must develop effective initiatives that address the unique positioning of Black women. Addressing race and gender inequity within the academy requires structural solutions (e.g., institutional change, sound faculty governance, and a new area of civil rights litigation); however, we focus here on peer mentoring (Benishek et al., 2004; Bova, 2000; Combs, 2003) and other practical tools of resistance to enhance the likelihood of continued success and advancement of Black women faculty members. The combined use of Black Feminist Thought and peer mentoring supports and values equity, provides an opportunity for the engaged parties to respect each other's individual power, expertise, and knowledge, and allows one to address the intersecting realities of the Black women's experience within the academy and beyond.

Peer mentoring also is consistent with African American women's reliance on networks and relationships with each other to adapt and survive the material conditions associated with race, gender, and class oppression (e.g., Combs, 2007). We view mentoring as a power-free partnership between a group of individuals where one individual usually has greater skills, experiences, and wisdom (Weinstein, 1998). Mentors may serve an intrinsic or psychosocial 
function, such as serving as a role model, confidant, and/or friend (Kerka, 1998), which is the less hierarchical aspect of traditional mentoring models. Peer mentors may provide psychosocial support (e.g., validation, emotional support, friendship, and mutuality). Mentoring relationships, whether peer or traditional, provide an instrumental career functions (i.e., sponsorship, coaching, corporate culture instruction; Cunningham, 1999).

Peer mentors provide assistance with career management via the sharing of information, strategizing, and feedback on work-related matters (Kram \& Isabella, 1985; Kerka, 1998). Giving advice and support in a warm and caring way to someone striving to become successful in a new work environment is central to the peer model. Some of the benefits of peer mentoring include, but are not limited to, assisting faculty members to discover their own voice and scholarly approach, socializing them into the academy, helping them to understand the spoken and unspoken departmental and institutional requirements, and establishing supportive relationships (Chesney-Lind, et al., 2006; Driscoll, Parkes, Tilley-Lubbs, Brill, \& Pitts Bannister, 2009; Girves, Zepeda, \& Gwanthmey, 2005; Holmes, Land, \& Hinton-Hudson, 2007). Because standards for successful performance outcomes often are unwritten and vague (AlexanderSnow \& Johnson, 1999), having a mentor to decode behaviors, cultural mores, expectations, and language are critical professional coping strategies (Mullen \& Hutinger, 2008). Effective peer mentoring relationships may reduce the likelihood of hostile competitiveness and allow collegial collaborations to manifest (Mullen \& Forbes, 2000). Additionally, peer mentoring can enhance faculty members' instructional practice and their understanding of race, gender, and privilege (Chesney-Lind, Okamoto, \& Irwin, 2006).

We suggest securing a cadre of supportive colleagues who have equal or complementary work styles and values, but also in which reciprocity is clearly an integral element in the peer relationship. One or two individuals cannot meet all of a person's professional needs, warranting the establishment and use of a mentoring network (McCormack \& West, 2006). Kram and Isabella's (1985) continuum of peer mentors provides a starting point of the varied types of mentors one might have in a network. There are three types of peer mentors that vary by levels of trust and by function: information peers, collegial peers, and special peers. Lower levels of trust, bonding, and limited sharing of personal information are characteristic of information peers. Individuals engaged in collegial peer teams have an intermediate level of trust; they share some personal information but tend to focus on career strategizing and give feedback on work issues. Special peers reflect the most intimate relationship and friendship where colleagues validate one another, provide emotional support, and give honest feedback to one another (Kram \& Isabelle). Most mentoring networks will have some combination of all three types of peer mentors.

\section{Resistance and a Black Woman's Standpoint}

African American women find themselves struggling against externallydefined representations and the continued questioning of the value and significance of our work within the academy (Chesney-Lind et al., 2006; Dillard, 
2000; Smith, 2000; Wright Myers, 2002), so here we speak of personal resistance. Historically, Black women have relied on a network and community of women to resist subordination and domination and to support their own self-definitions and self-valuations, which continues to be an excellent form of personal resistance. We also must reclaim and re-interpret that which has been denigrated and confront the often invisible devaluing of Black women in academe. Creating counter-narratives in which we are capable, smart, hardworking, productive, and legitimate scholars is another form of resistance (Fries-Britt, \& Kelly, 2005; Patton, 2004ab; Thomas \& Hollenshead, 2006). We also must resist the internalization of marginalization within the academy and fully embrace the belief that we have earned the right to be in the academy. We will not allow the treatment from others to stand in the way of our successful performance. We, as Black women, must ask ourselves, "Who has the problem?" To address race and gender inequity, we sometimes must enlist a variety of strategies, which at times may directly confront racism and sexism (Smith, 2000). We also must use other forms of indirect resistance, such as focusing our energies on our work in the best-fitting departments.

To counter negative race and gender ideologies of students and to resist White privilege in the academy, we recommend using other teaching and learning evaluation tools (e.g., Teacher Behaviors Inventory) to complement university teaching evaluations, and to carefully document teaching successes and instructional workshops attended; these are functional forms of resistance. Being planful and engaging in careful course administration are excellent tools of resistance, such as using reflective writing in the class to help students connect course content and your committed investment in their learning.

Using the peer evaluation as a tool of resistance also proves useful. In dire cases, ask a White colleague who has won a teaching award, desires to support your success, and holds a consciousness of inclusion to conduct a peer evaluation which may lend credence to one's instructional excellence. The current approach can be effective when students and colleagues lack an inclusive consciousness and appraisals of one's instruction have been questioned. Although this approach in some ways validates the lack of credence given to Black women faculty, it sometimes becomes the best weapon to diffuse a hostile learning environment and allows one to focus on the tasks at hand - instructional excellence seasoned with one's scholarly expertise and preferred pedagogical approach.

African American women in higher education have a privileged position with respect to educational and graduate degree attainment, which is a source of social mobility for many of us. Many African American women scholars, however, are a part of extended families and home communities that are not middle-class or economically privileged, and, thus, have financial, generativity, and mentoring obligations to less resourced families and communities. Our second shift extends beyond our caregiving jobs as educators; it carries over into our roles as wives, mothers, community leaders, and mentors of those who do not have access to the ranks (Chesney-Lind et al., 2006), that create additional demands on our psyches, resources, ans spirits, leaving us exhausted on many days (Jones \& Shorter-Gooden, 2004). As a result, some Black women in 
academe face challenges related to finances and intangible social support resources, which is especially true for graduate students and upwardly mobile faculty members. Strategies we suggest for managing our extended second shift include: seek out information related to finding funding sources for research and instruction, ongoing professional development, and other less visible needs when relocating for a job (e.g., churches, cleaners, quality child care, etc). Additionally, during the interview and recruitment processes we must negotiate an efficient package with salary, health and retirement benefits, start-up funds, computers, software, and other viable resources (Henderson, 2010).

Last, when interviewing, secure time to examine community resources, such as the church that also may provide some much needed information and support for Black women in academe. To do so may require spending another day and half during the onsite interview or returning to visit once an offer is made. Churches and community leaders may help one learn about the history and politics of a place and where to secure needed personal and professional services. Community and church members may make referrals to the best health care professionals, and identify other coded norms that may reduce the stress of entering a new living and work environment.

Universities and departments that have a firm commitment to being inclusive and promoting the successful professional development of Black women faculty may use institutional models that include a time for incoming faculty members to meet with faculty of color or from diverse walks a life, and meeting with the university Work-life Resource person to learn how the university provides or fails to provide reserved child care, summer camps, and other extracurricular and community activities for their family. The university may facilitate the identification of social support resources, especially given that Black women in the academy is a place of privilege and challenge simultaneously.

Returning to the tensions and representations of the academic domestic and Sapphire, Black women faculty must lay down our Aunt Jemima hats, choose when we desire to serve and sacrifice, share the service burdens with our colleagues, and seek advice from a trusted mentor or colleague about whether a task is in one's best interest. We must protect our work-life balance by using programs or policies (O'Connor, 2000), such as family leave for parenting and other caregiving needs. At all costs, we must not shy away from using Stop-theClock options and other personal well-being options (e.g., counseling, mental health days, and no as a response). We must judiciously select the committees and tasks that are meaningful to us, and find creative, yet deliberate ways to have congruency and overlap between our service, instruction, and research to reduce stress and enhance one's productivity (Chesney-Lind, et al., 2006).

\section{Summary}

As African American women continue to prepare themselves academically for university positions, Black Feminist Thought provides a historical and contextual framework for the tensions that shape our experiences. Researchers have examined the narratives, dialogues, and interactions of Black women faculty 
members and colleagues (Alexander-Snow \& Johnson; Bova, 2000; Burke et al., 2000; Wright Myers, 2002) that may serve to enhance and encourage the awareness and understanding of inequities and the complexities of the experiences of our lives. Black women faculty members often painfully recount race, gender, and their intersection as sources of oppression that shape our experiences within the academy (e.g., Burton et al., 2000; Fries-Brit \& Kelly, 2005; Patton, 2004b). Consequently, we summarized some of the tensions associated with African American women's outsider within status: (a) inequality without reverence to credentials, expertise, and professional experiences, (b) the mammy-sapphire continuum of existence, and (c) the unacknowledged influences of White privilege and the interlocking nature of race and gender oppression within the academy.

Yet, as we approach academic institutions, we must remember that the halls of higher education are filled with people whose life experiences and personal abilities may not allow them to shift toward inclusiveness and a commitment to equity and justice. Historical and longstanding values, be it racist, sexist, or classist, will change only one relationship at a time, and with sustained efforts toward institutional transformation. In the meantime and in the absence of institutional reform, we offer effective peer mentoring that is characterized by mutual edification, interdependence, and the inclusion of functional and psychosocial support, as a tool of resistance, coping, and transformation. Resistance is a continuum of strategies that include counter-narratives defined and evaluated by Black women faculty, securing resources to sustain one's work, relinquishing representations offered by others, sharing the work and inclusive service with our colleagues, and seeking and using work-life resources and practices. For we are not wrong; our professional lives are our own; and our resistance is our self-determination (Jordan, 2005), biographical narratives seasoned with many other tools of resistance.

\section{References}

Alexander-Snow, M., \& Johnson, B. J. (1999). Perspectives from faculty of color. In R. J. Menges and Associates. Faculty in New Jobs (pp. 88-117). San Francisco, CA: Jossey-Bass.

Benishek, L. A., Bieschke, K. J., Park, J. \& Slattery, S. M. (2004). A multicultural feminist model of mentoring. Journal of Multicultural Counseling and Development, 32, 428-442.

Bova, B. (2000). Mentoring revisited: The Black woman's experience. Mentoring and Tutoring, 8, 5-16.

Burke, B. B, Cropper, A., \& Harrison, P. (2000) Real or imagined-Black women's experiences in the Academy. Community, Work \& Family, 3, $297-$ 310 . 
Carter-Black, J. (2008). A Black woman's journey into a predominately White academic world. Affilia. 23(2), 112-122.

Chesney-Lind, M., Okamoto, S. K., \& Irwin, K. (2006). Thoughts on feminist mentoring: Experiences of faculty members from two generations in the academy. Critical Criminology, 14, 1-21.

Hill Collins, P. (1986). Learning from the outsider within: The sociological significance of Black feminist thought. Social Problems, 33 (6), S14-S32.

Hill Collins, P. (1991). Black feminist thought: Knowledge, consciousness, and the politics of empowerment. New York: Routledge.

Combs, G. M. (2003). The duality of race and gender for managerial African American women: Implications of informal social networks on career advancement. Human Resource Development Review. 2(4), 385-405.

Cunningham, S. (1999). The nature of workplace mentoring relationships among faculty members in Christian higher education. Journal of Higher Education, 70, 441-463.

Dillard, C. R. (2000). The substance of things hoped for, the evidence of things not seen: examining an endarkened feminist epistemology in educational research and leadership. Qualitative Studies in Education, 13, 661-681

Driscoll, L. G., Parkes, K. A., Tilley-Lubbs, G. A., Brill, J. M., \& Pitts Banister, V. R. (2009). Navigating the lonely sea: Peer mentoring and collaboration among aspiring women scholars. Mentoring and Tutoring: Partnerships in Learning, 17, 5-21.

Few, A. L., Piercy, F. P., \& Stremmel A. (2007). Balancing the passion for activism with the demands of tenure: One professional's story from three perspectives. NWSA Journal, 19(3), 47-66.

Franklin, C.W., Jr., \& Richardson, L. (1972). Toward a paradigm of substructural relations: An application of sex and race in the United States. Phylon, 33, 242253.

Fries-Britt, S., \& Kelly, B. T. (2005). Retaining each other: Narratives of two African American women in the academy. The Urban Review, 37(3), 221-242.

Girves, J. E., Zepeda, Y., \& Gwanthmey, J. K. (2005). Mentoring in a postaffirmative action world. Journal of Social Issues, 61, 449-479. 
Harley, D. A. (2008). Maids of academe: African American women faculty at predominately White institutions. Journal of African American Studies, 12, 19-36.

Harris, T. (2007). Black feminist thought and cultural contracts: Understanding the intersection and negotiation of racial, gendered, and professional identities in the academy. New Directions for Teaching and Learning, 110, 55-64.

Henderson, T. L. (2010). AdvanceVT: Professional development tool. Retrieved on March 27, 2010 from http://ches.okstate.edu/documents/2010AdvanceVT_Professional_Developmen t Tools3.pdf.

Holmes, S. L., Land, L. D., \& Hinton-Hudson, V. D. (2007). Race still matters: Considerations for mentoring Black women in academe. Negro Educational Review, 58(1-2), 105-129.

Jones, C., \& Shorter-Gooden, K. (2004). Shifting: The double lives of Black women in America. New York: Perennial.

Jordan, J. (2005). Poem about my rights. Retrieved on April 15, 2010 from http://www.poetryfoundation.org/archive/print.html?id=178526.

Kerka, S. (1998). New perspectives on mentoring (ERIC/ACVE Digest \#194). Retrieved on February 25, 2010 from http://www.eric.ed.gov/ERICDocs/data/ericdocs2sql/content_storage_01/0000 019b/80/15/5e/50.pdf.

Kram, K. E., \& Isabella, L. A. (1985). Mentoring alternatives: The role of peer relationships in career development. Academy of Management Journal, 28, 110-132.

McCormack, C., \& West. D. (2006). Facilitated group mentoring develops key career competencies for university women: A case study. Mentoring and Tutoring, 14, 409-431.

McIntosh, P. (1995). White privilege and male privilege: A personal account of coming to see correspondences through work in Women' Studies. In M. L. Andersen and P. H. Collins (Eds.) Race, class, and gender: An anthology (pp. 76 - 87). Belmont, CA: Wadsworth.

Mullen, C. A. (2005). The mentorship primer. New York: Peter Lang.

Mullen, C. A., \& Forbes, S. A. (2000). Untenured faculty: Issues of transition, adjustment and mentorship. Mentoring and Tutoring, 8, 31-46. 
Mullen, C. A., \& Hutinger, J. L. (2008). At the tipping point? Role of formal faculty mentoring in changing university research cultures. Journal of InService Education, 34, 181-204.

O'Connor, P. (2000). 12 ways academic women can resist. Women in Higher Education. 9, 7-8.

Patton, T. O. (2004a). In the guise of civility: The complicitous maintenance of inferential forms of sexism and racism in higher education. Women's Studies in Communication, 27, 60-87.

Patton, T. O. (2004b). Reflections of a Black woman professor: Racism and Sexism in academia. The Howard Journal of Communications, 15, 185-200.

Smith, P. J. (2000). A message to sapphire and her sisters in academia. Women in Higher Education, 9, 31-34.

Thomas, G., \& Hollenshead, C. (2001). Resisting from the margins: The coping strategies of black women and other women of color faculty members at a research university. The Journal of Negro Education, 70, 166-175.

Wagner, T. A. (2004). Women in science and engineering: A review of selected topics. Retrieved on March 19, 2010 from http://www.advance.vt.edu/Resources_and_Links/Literature_Review/Literatur e_Review.htm.

Weinstein, E. (1988). Mentoring for success. America Media: Des Moines, IA.

Wright Myers, L. (2002). A broken silence: Voices of African American women in the academy. Westport, CT: Bergin \& Garvey. 